DOE/OR\&́|02-1322\&D1

\title{
Action Memorandum for the \\ Waste Area Grouping 1 Tank WC-14 Removal Action at Oak Ridge National Laboratory \\ Oak Ridge, Tennessee
}
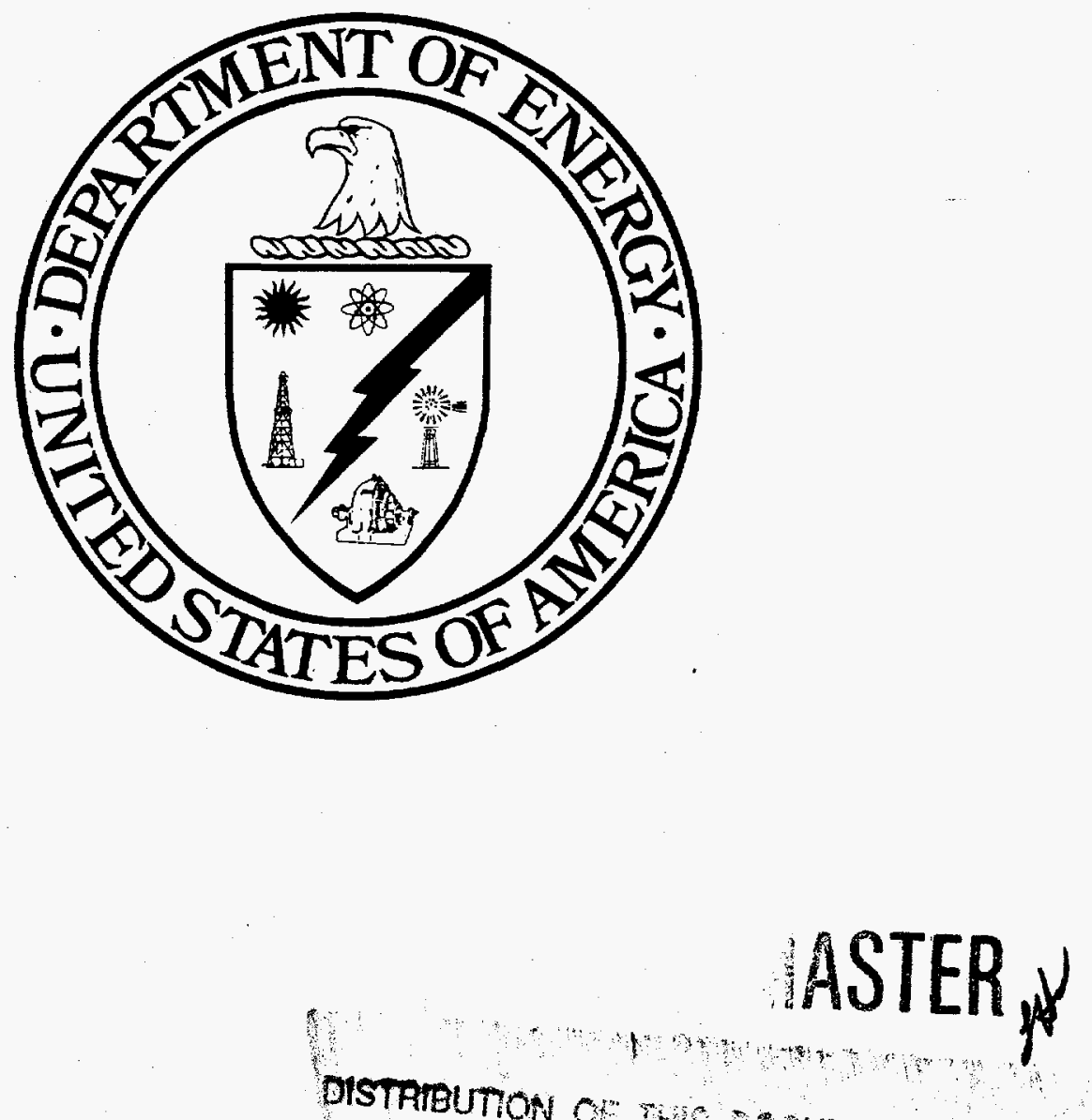

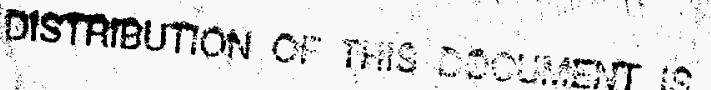




\section{DISCLAIMER}

This report was prepared as an account of work sponsored by an agency of the United States Government. Neither the United States Government nor any agency thereof, nor any of their employees, makes any warranty, express or implied, or assumes any legal liability or responsibility for the accuracy, completeness, or usefulness of any information, apparatus, product, or process disclosed, or represents that its use would not infringe privately owned rights. Reference herein to any specific commercial product, process, or service by trade name, trademark, manufacturer, or otherwise does not necessarily constitute or imply its endorsement, recommendation, or favoring by the United States Government or any agency thereof. The views and opinions of authors expressed herein do not necessarily state or reflect those of the United States Government or any agency thereof. 


\section{DISCLAIMER}

Portions of this document may be illegible electronic image products. Images are produced from the best available original document. 


\title{
Action Memorandum for the Waste Area Grouping 1 Tank WC-14 Removal Action at Oak Ridge National Laboratory \\ Oak Ridge, Tennessee
}

Date Issued-November 1994

\author{
Prepared by \\ Jacobs ER Team \\ 125 Broadway Avenue \\ Oak Ridge, Tennessee \\ under contract DE-AC05-93OR22028 \\ Prepared for \\ U.S. Department of Energy \\ Office of Environmental Restoration and Waste Management
}




\section{ACKNOWLEDGEMENTS}

This document was prepared by the Jacobs ER Team under prime contract to the U.S. Department of Energy. Team members are:

Jacobs Engineering Group Inc.

Geraghty \& Miller, Inc.

Lockwood Greene Technologies, Inc.

PAI Corporation

Solutions To Environmental Problems

United Science Industries

University of Tennessee

Additional support was given to the team by Martin Marietta Energy Systems, Inc. 


\section{CONTENTS}

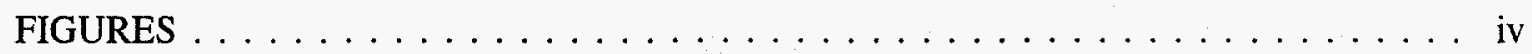
ACRONYMS AND ABBREVIATIONS $\ldots \ldots \ldots \ldots \ldots \ldots \ldots$

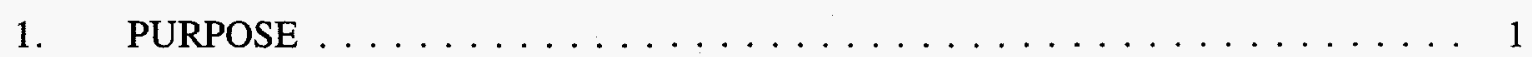

2. SITE CONDITION AND BACKGROUND $\ldots \ldots \ldots \ldots \ldots \ldots$

2.1 SITE DESCRIPTION $\ldots \ldots \ldots \ldots \ldots \ldots \ldots \ldots \ldots \ldots \ldots$

2.1 .1 Physical Location $\ldots \ldots \ldots \ldots \ldots \ldots \ldots \ldots$

2.1.2 Removal Site Evaluation . . . . . . . . . . . . . . . 3

2.1 .3 Site Characteristics .................... 3

2.1.4 Release or Threatened Release of Contaminants . . . . . . . . . 5

2.1.5 National Priorities List Status . . . . . . . . . . . . . . . 5

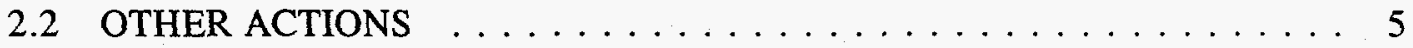

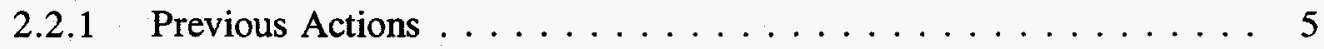

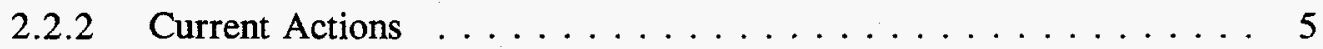

2.3 ROLES OF STATE AND LOCAL AUTHORITIES $\ldots \ldots \ldots \ldots \ldots$

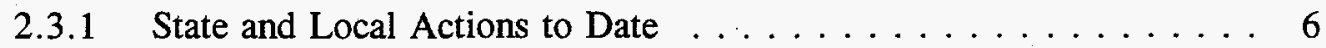

2.3.2 Potential for Continued Response ............... 6

3. THREATS TO PUBLIC HEALTH OR WELFARE OR THE ENVIRONMENT, AND STATUTORY AND REGULATORY AUTHORITY $\ldots \ldots \ldots \ldots \ldots$

3.1 THREATS TO PUBLIC HEALTH OR WELFARE $\ldots \ldots \ldots \ldots \ldots$

3.2 THREATS TO THE ENVIRONMENT $\ldots \ldots \ldots \ldots \ldots \ldots \ldots$

4. ENDANGERMENT DETERMINATION $\ldots \ldots \ldots \ldots \ldots \ldots$

5. PROPOSED ACTION AND ESTIMATED COST $\ldots \ldots \ldots \ldots \ldots \ldots \ldots$

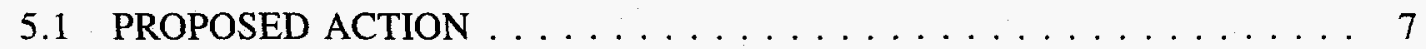

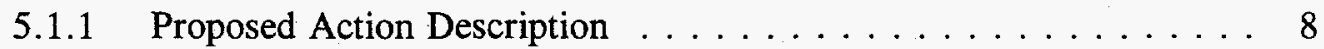

5.1 .2 Contribution to Remedial Performance . . . . . . . . . . . 8

5.1 .3 Description of Contingency Technologies $\ldots \ldots \ldots \ldots$

5.1 .4 Administrative Record Documentation ... . . . . . . . . . . . 9

5.1.5 Applicable or Relevant and Appropriate Requirements . . . . . . . . 9

5.1 .6 Project Schedule . . . . . . . . . . . . . . . . 10

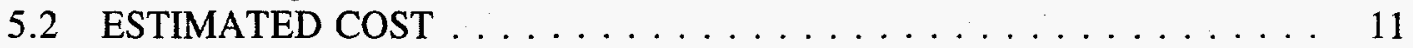

6. EXPECTED CHANGE IN THE SITUATION SHOULD ACTION BE DELAYED OR NOT IMPLEMENTED $\ldots \ldots \ldots \ldots \ldots \ldots \ldots \ldots \ldots \ldots \ldots \ldots$

7. OUTSTANDING POLICY ISSUES $\ldots \ldots \ldots \ldots \ldots \ldots \ldots$

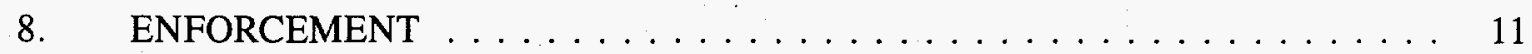




\section{CONTENTS (continued)}

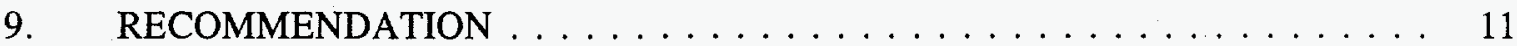

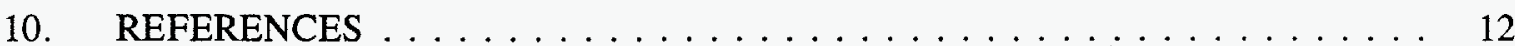

APPENDIX A: U.S. DEPARTMENT OF ENERGY AND U.S. ENVIRONMENTAL PROTECTION AGENCY

LETTERS

A-1

\section{FIGURES}

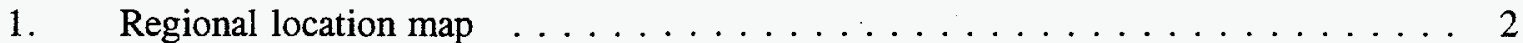

2. WC-10 Tank Farm . . . . . . . . . . . . . . . . . . . . . . 4 


\section{ACRONYMS AND ABBREVIATIONS}

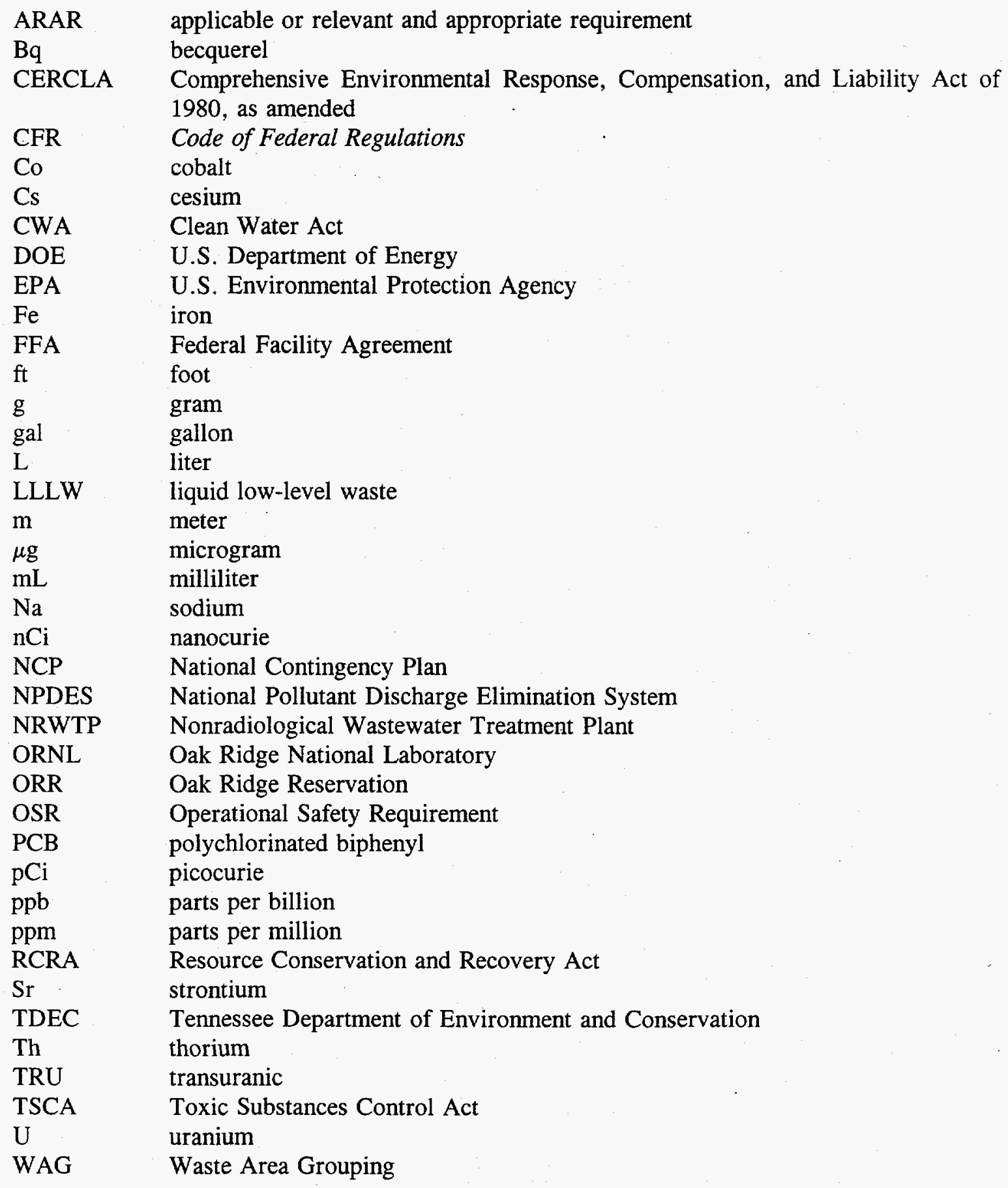


ACTION MEMORANDUM FOR THE

\section{WASTE AREA GROUPING 1 TANK WC-14 REMOVAL ACTION AT OAK RIDGE NATIONAL LABORATORY \\ OAK RIDGE, TENNESSEE}

APPROVAL

W. N. Lingle, Federal Facility Agreement Project Manager

Date

Environmental Restoration Division

U.S. Department of Energy Oak Ridge Operations Office 


\section{PURPOSE}

This action memorandum documents approval for a Comprehensive Environmental Response, Compensation, and Liability Act of 1980, as amended (CERCLA), time-critical action. The action will remove radiologically contaminated water from Tank WC-14. The water contains a polychlorinated biphenyl (PCB) at a level below regulatory concern. Tank WC-14 is located in the Waste Area Grouping (WAG) 1 WC-10 Tank Farm at the Oak Ridge National Laboratory (ORNL), Oak Ridge, Tennessee. Contaminated sludge remaining in the tank after removal of the liquid will be the subject of a future action.

\section{SITE CONDITION AND BACKGROUND}

\subsection{SITE DESCRIPTION}

\subsubsection{Physical Location}

ORNL is located on the U.S. Department of Energy (DOE) Oak Ridge Reservation (ORR) in East Tennessee at the Anderson and Roane county line approximately 25 miles west of Knoxville, Tennessee, and 10 miles southwest of the city of Oak Ridge (Fig. 1). The facility is accessible by taking U.S. Interstate 40 to Tennessee Highway 95 or taking the Pellissippi Parkway. The parkway begins at U.S. Interstate Highways 40 and 75 in West Knoxville and continues toward the city of Oak Ridge where the road name changes to Bethel Valley Road.

Bounding ORR on the south and west is Clinch River. Across Clinch River on the southern and western sides is private rural land used primarily for farming. Portions of ORR have been declared a wildlife management area by DOE and the Tennessee Wildlife Resources Agency. Hunting is permitted on some of this land.

The headwaters of White Oak Creek, including the Fifth Creek tributary of White Oak Creek, begin within ORR. White Oak Creek flows through ORNL, passing WAG 1, the main plant area, on the south. Fifth Creek joins White Oak Creek toward the eastern end of the plant,

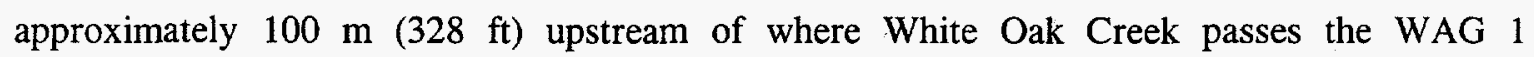
impoundments.

WAG 1, including the WC-10 Tank Farm, White Oak Creek, and Fifth Creek, lies within the restricted ORNL main plant area, thus preventing public access to the tank farm area. The 


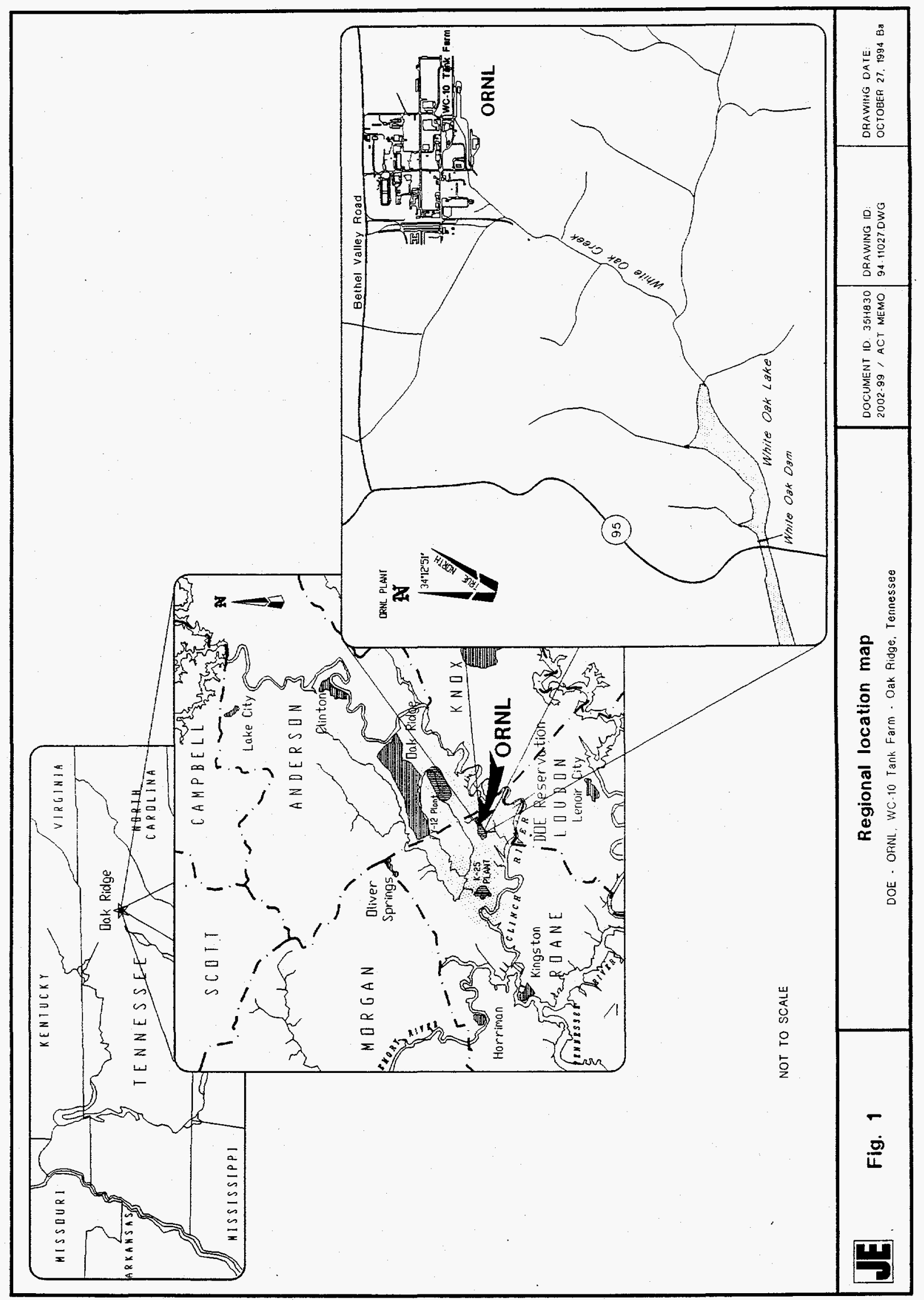


WC-10 Tank Farm is further restricted administratively and physically (the tanks are buried and tank accesses are contained in a building) to ORNL employees with access for only properly trained and protected personnel.

\subsubsection{Removal Site Evaluation}

Tank WC-14 was used for the collection and transfer of liquid low-level waste (LLLW) from processes, sumps, and laboratories in Buildings 4501 and 4507. It was installed in the early 1950s and was removed from programmatic service effective January 1, 1992. Tank WC-14 contains residual waste (both aqueous and sludge phases) from past operations and receives nonprogrammatic inflow.

The aqueous phase in Tank WC-14 was sampled in November 1992. At that time, the tank contained 946-1,135 L (250-300 gal) of liquid and nonprogrammatic inflow was calculated at a rate of approximately $132 \mathrm{~L}$ (35 gal) per month. Sampling results indicated elevated levels of beta/gamma emitters $\left({ }^{137} \mathrm{Cs}\right.$ was at a level of $\left.5.5 \times 10^{4} \mathrm{~Bq} / \mathrm{mL}\left[1.49 \times 10^{9} \mathrm{pCi} / \mathrm{L}\right]\right)$. At the same time, the pesticide/PCB analysis indicated $278 \mathrm{ppb}$ of the PCB Aroclor 1248. The tank was resampled for PCBs in August 1993 and results indicated the presence of the PCB at a concentration of approximately $7 \mathrm{ppb}$. Laboratory results also indicate that the concentrations of metals are below Resource Conservation and Recovery Act (RCRA) regulatory concern.

Approximately $189 \mathrm{~L}$ (50 gal) of sludge are contained in Tank WC-14. Core samples of the sludge were collected in March and August 1993. Analytical results of the sludge phase for Tank WC-14 show elevated levels of alpha emitters, europium isotopes, ${ }^{137} \mathrm{Cs},{ }^{60} \mathrm{Co}$, and ${ }^{90} \mathrm{Sr}$. It is also contaminated with the PCB Aroclor 1248 ranging from 105-241 ppm and exhibits RCRA characteristics, based on the laboratory analyses of metals. The sludge is defined as a transuranic (TRU) waste, containing approximately $1,000 \mathrm{nCi} / \mathrm{g}$ (wet basis) of TRU elements with half-lives greater than 20 years.

\subsubsection{Site Characteristics}

The WC-10 Tank Farm in which Tank WC-14 is located is situated near the northwest corner of the intersection of White Oak Avenue and Fifth Street (Fig. 2). The tank is vertically oriented and dish bottomed, with a 4,345-L (1,148-gal)-capacity. It rests on a concrete "saucer," which is provided with a sump and a dry well for monitoring the groundwater. The tank is buried approximately $2.4 \mathrm{~m}(8 \mathrm{ft})$ underground. 


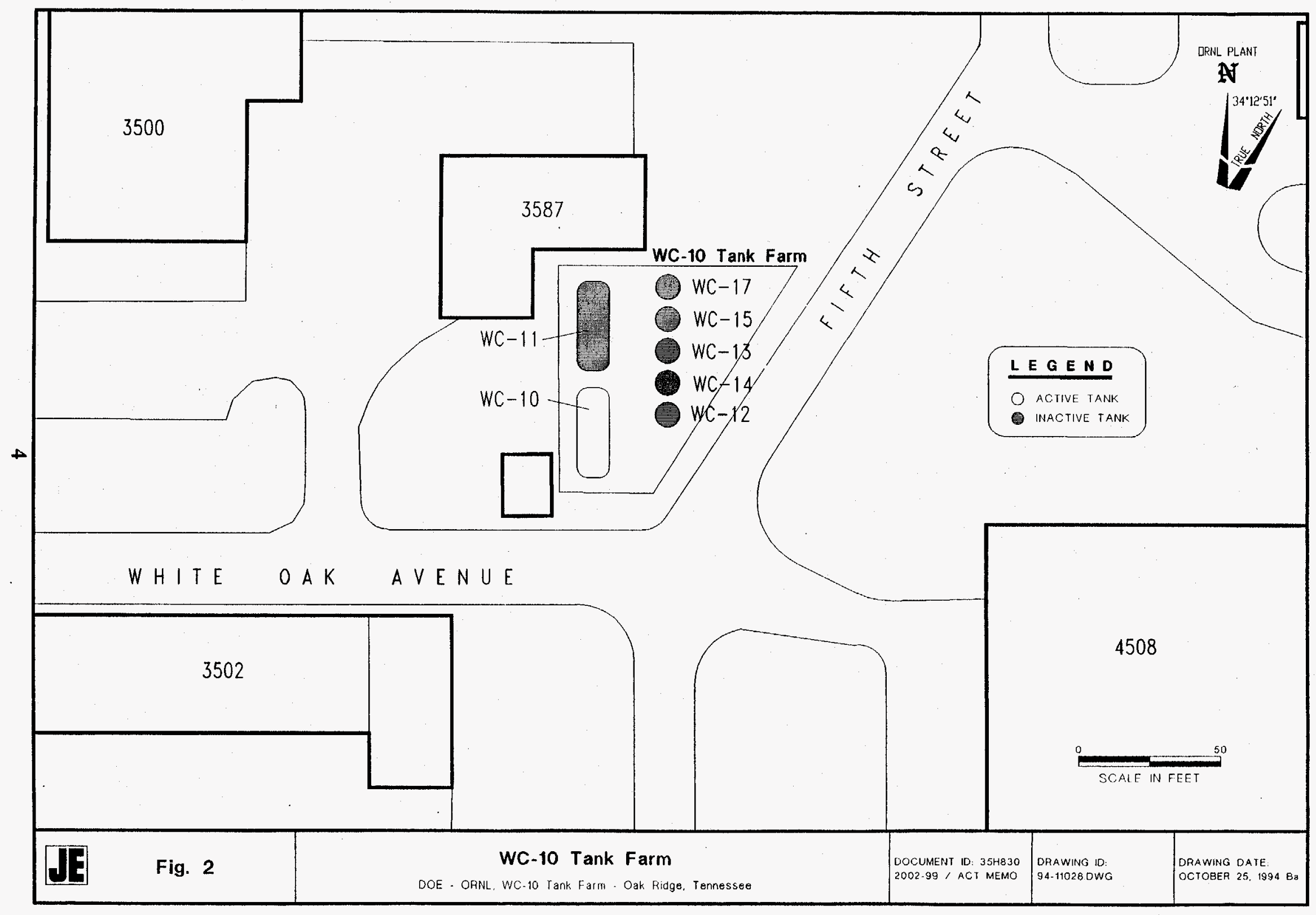




\subsubsection{Release or Threatened Release of Contaminants}

This removal action covers only the aqueous-phase contents of Tank WC-14. The contaminants of concern in the liquid are ${ }^{137} \mathrm{Cs}$ and ${ }^{90} \mathrm{Sr}$, CERCLA hazardous substances. The liquid also contains trace levels (less than $1 \mathrm{ppm}$ ) of a PCB regulated by the Toxic Substances Control Act (TSCA).

The threat of release of the contaminated liquid from Tank WC-14 is based on the current volume in the tank and continued nonprogrammatic inflow. The tank is more than 60 percent filled (approximately 2,460 L [650 gal] with liquid and $189 \mathrm{~L}$ [50 gal] of sludge) and nonprogrammatic inflow is approximately $132 \mathrm{~L}$ (35 gal) per month. The ORNL Operational Safety Requirement (OSR) limit for this tank is 90 percent of capacity. If the tank reaches the OSR limit, an action to reduce the volume in the tank must be initiated within 24 hours. The standard policy at ORNL is to keep the volume in the tanks below 60 percent of capacity to reduce the possibility of violating the OSR.

\subsubsection{National Priorities List Status}

As a result of the risk to human health and the environment by past waste disposal practices, ORR was placed on the National Priorities List in 1989. DOE, the U.S. Environmental Protection Agency (EPA), and the Tennessee Department of Environment and Conservation (TDEC) entered into a Federal Facility Agreement (FFA) that establishes interagency procedures, defines the decision-making process, and establishes schedules for environmental restoration on ORR (DOE 1992).

\subsection{OTHER ACTIONS}

\subsubsection{Previous Actions}

No attempt has been made to remove the aqueous phase from Tank WC-14 since the PCB, above the regulatory reporting limit, was detected in the March 1993 sludge characterization effort. Correspondence is documented in Section 5.1.4.

\subsubsection{Current Actions}

Activities are underway to reduce the nonprogrammatic inflow to Tank WC-14. The level of the tank contents is monitored continuously at the ORNL Waste Operations Control Center. 


\subsection{ROLES OF STATE AND LOCAL AUTHORITIES}

\subsubsection{State and Local Actions to Date}

The state of Tennessee is a party to the FFA under which the removal action at Tank WC-14 is being performed. TDEC and EPA have participated in the decision for this timecritical removal action and have assisted DOE in developing an appropriate method to meet the CERCLA regulatory requirements.

\subsubsection{Potential for Continued Response}

The time-critical removal action is being coordinated with EPA and TDEC and will proceed upon approval by DOE of this action memorandum.

\section{THREATS TO PUBLIC HEALTH OR WELFARE OR THE ENVIRONMENT, AND STATUTORY AND REGULATORY AUTHORITY}

Section 104 of CERCLA addresses the response to releases or threats of releases through removal actions. Executive Order 12580 delegates to DOE the response authority for all DOE actions relating to a hazardous substance, pollutant, or contaminant that is released or threatens to be released into the environment when the contaminant presents an imminent and substantial danger to the public health or welfare. As part of its removal action authority, DOE can undertake any type of investigation, survey, or testing necessary to plan, design, and carry out the removal action. The violation of the OSR, which would prevent an overflow of the liquid, is considered serious enough to warrant a time-critical removal action of the aqueous phase from Tank WC-14.

\subsection{THREATS TO PUBLIC HEALTH OR WELFARE}

There is a potential risk to public health and welfare and to the environment due to the presence of radiological and hazardous constituents contained in the liquid and sludge in Tank WC-14. Because of the presence of the PCB, the tank was not routinely emptied into the LLLW system when its volume reached 60 percent of capacity. The tank is now more than 60 percent filled and nonprogrammatic inflow continues at the rate of $132 \mathrm{~L}$ (35 gal) per month. There is 
no evidence that the contents of Tank WC-14 are leaking from the tank and no leaks or spills into the soil surrounding the tank have been detected. However, the effluence from Tank WC-14, if released, could possibly present a risk to the public because of proximity to Fifth Creek, which could transport the radioactive material and the PCB into White Oak Creek.

\subsection{THREATS TO THE ENVIRONMENT}

A threat to the environment is possible only if the contents of the tank leak or spill into the soil and reach Fifth Creek, which could transport the contamination beyond the WC-10 Tank Farm area and affect environmental receptors.

\section{ENDANGERMENT DETERMINATION}

Actual or threatened releases of radioactive materials and the PCB from Tank WC-14, if not addressed by implementing the response action selected in the action memorandum, may present an endangerment to public health or welfare or to the environment.

\section{PROPOSED ACTION AND ESTIMATED COST}

Under this time-critical action for Tank WC-14, DOE will remove enough liquid to lower the total volume of waste in the tank to approximately 10 percent of the tank's capacity. The aqueous phase contains elevated levels of beta/gamma emitters, primarily ${ }^{137} \mathrm{Cs}$ and ${ }^{90} \mathrm{Sr}$, and trace levels of a PCB. Removal of the aqueous phase will reduce the risk of potential overflow. It is DOE's position that this action will not change the current regulatory status of the LLLW system.

\subsection{PROPOSED ACTION}

The radiologically contaminated liquid (which contains less than $1 \mathrm{ppm}$ PCB) being stored in Tank WC-14 will be transferred into the active LLLW system. A low-volume pump will be used so that the more highly contaminated sludge in the bottom of the tank is not disturbed or removed from the tank during this action.

The aqueous contents of the tank will be transferred to the LLLW evaporator via the active LLLW system. Wastes from the liquid (the radiological contaminants and PCB 
component) will be concentrated at the evaporator and transferred to the Melton Valley Storage Tanks for long-term storage. Overheads (liquids evaporated and then condensed) from the evaporator will be processed through the Process Waste Treatment Plant and subsequently through the Nonradiological Wastewater Treatment Plant (NRWTP).

\subsubsection{Proposed Action Description}

The active LLLW system pipe lines are accessible in the area of the WC-10 Tank Farm. A hose connected to a low-volume vacuum pump will be inserted into the aqueous phase of the tank. The end of this hose will not be placed in the vicinity of the sludge phase to avoid pulling sludge into the liquid being evacuated. From the pump, the liquid will be transferred into the active LLLW system via a riser that is accessible in the WC-10 Tank Farm. A temporary storage container(s) may be used to hold the liquid before it is released into the active LLLW system. The pumping will continue until the volume is lowered to approximately 10 percent of tank capacity without disturbing the sludge phase.

As the aqueous phase is pumped from the tank, it will pass through a clear plastic hose on its way to the active LLLW system. The liquid passing through the clear portion of hose will be continuously monitored for color and clarity. Any change in the color and/or clarity will be an indication that solids and/or elements from the sludge phase may be in the line. The hose will be arranged so that pumping can be stopped before the contents of the hose enter the discharge lines and any sludge in the hose can be returned to the tank.

When pumping is completed, the hose and any temporary storage container(s) used will be decontaminated by flushing with clean water while still attached to the active LLLW system. As a result, no waste transport or disposal (other than personal protective equipment) is anticipated.

\subsubsection{Contribution to Remedial Performance}

This action will reduce the risk of overflow of liquid wastes from the tank. Outside of the action described in this memorandum, but contributing to the eventual remediation of the tank, are two DOE efforts: the location of sources and control of the inflow of nonprogrammatic liquids into the tank and the evaluation of in situ treatment technologies for PCB-contaminated sludges. This time-critical removal action will allow DOE to complete these efforts and implement the results during the Tank WC-14 remediation. 


\subsubsection{Description of Contingency Technologies}

With the exception of the presence of the PCB, this procedure is routine, hence a contingency technology has not been selected.

\subsubsection{Administrative Record Documentation}

The administrative record file for this action was initiated by a Letter of Notification sent by DOE to EPA and TDEC (dated January 28, 1994) advising them of the need for this timecritical removal action. The response from EPA, dated August 17, 1994, concurs and recognizes the need for action and regulatory strategy. This action memorandum, along with a copy of the documents referenced in the memorandum, completes the administrative record for this timecritical removal action.

\subsubsection{Applicable or Relevant and Appropriate Requirements}

In accordance with Section 300.415(i) of the National Contingency Plan (NCP), on-site removal actions conducted under CERCLA are required to attain applicable or relevant and appropriate requirements (ARARs) to the extent practicable, considering the exigencies of the situation. The NCP identifies two factors that should be considered in determining whether identifying and complying with ARARs is practicable: (1) the urgency of the situation, and (2) the scope of the removal action to be taken. The level of liquid waste in the tank and the possibility of release of that liquid warrants a time-critical response, but not an emergency response.

There are no location-specific ARARs associated with this action. It is not located in a floodplain or a wetland; no threatened or endangered species or habitats have been identified at the site; and it has no potential to affect any archaeological or historic resources.

There are no action-specific ARARs associated directly with this action. The action will take place in an enclosed system of hoses and piping within a building, thus, no releases to air, water, or soil are anticipated. RCRA exempts Clean Water Act (CWA)-permitted wastewater facilities, including all ancillary equipment (i.e., pipelines, tanks, sumps, and collection systems) from hazardous waste requirements (40 Code of Federal Regulations (CFR) 270.1(c)(2); 53 Federal Register 34079 [September 1, 1988]). Although the liquid is not being considered TSCA-regulated (see below), the Liquid Waste Laboratory Certification Official has been notified of a possible inconsistency with the waste acceptance criterion covering the introduction of TSCA hazardous materials into the LLLW system, as defined in Oak Ridge National Laboratory Liquid Waste Treatment Systems Waste Acceptance Criteria (Parrott et al. 1991) and appropriate documentation has been prepared. Before any discharge to surface waters, overheads from the 
evaporator will be processed through the NRWTP, a National Pollutant Discharge Elimination System (NPDES)-permitted facility.

Chemical-specific ARARs exist for ${ }^{137} \mathrm{Cs},{ }^{90} \mathrm{Sr}$, and the PCB present in the aqueous phase. However, compliance with the requirements of 10 CFR 834 for protection of the public from radiation will be assured because the action will be performed in an enclosed facility and the material is being transferred to a permitted treatment facility. Although not an ARAR or "to be considered" guidance, DOE Order 5480.11, "Radiation Protection for Occupational Workers," procedures and standards must also be followed during the action to protect workers from ionizing radiation due to high levels of ${ }^{137} \mathrm{Cs}$ and ${ }^{90} \mathrm{Sr}$. Compliance with $\mathrm{CWA}$ requirements for and discharge to surface water bodies will be assured because the overheads will ultimately be transferred to a facility meeting its NPDES permit limitations.

According to 40 CFR 761.1(b) which implements TSCA; for a mixture of liquids and solids, if industrial sludges and slurries are processed (e.g., separation of liquid and nonliquid phases), the original PCB concentration applies to the processed material, regardless of the actual PCB concentration. One purpose of this "anti-dilution" rule is to prevent the use of dilution as a means of avoiding treatment and disposal requirements. Since the sludge phase in the tank contains a PCB in the range of $105-241 \mathrm{ppm}$, application of this rule would require the aqueous phase of the tank to be considered to have similar PCB concentrations.

However, EPA has clarified that for CERCLA response actions the anti-dilution rule provisions are only. applicable once a remedial action is initiated. In selecting response action strategies and cleanup levels under CERCLA, the form and concentration of the PCB contamination should be evaluated on an "as found" basis on the site (EPA 1990). In this case, the liquid phase of the tank contents, which has a concentration of $7 \mathrm{ppb}$ of a PCB, is below the $50 \mathrm{ppm}$ regulatory limit for PCB waste. This time-critical removal action is being taken in response to the potential risk posed by radiological contamination and is limited in scope to the aqueous phase. Additional concurrence with respect to the acceptability of this response action was provided in a letter from the Region IV EPA Office (dated August 17, 1994).

\subsubsection{Project Schedule}

This removal action will be initiated by February 17, 1995 and is expected to be completed in one day. 


\subsection{ESTIMATED COST}

The estimated cost for field activities is $\$ 10,000$.

\section{EXPECTED CHANGE IN THE SITUATION SHOULD ACTION BE DELAYED OR NOT IMPLEMENTED}

Should the proposed action be delayed or not implemented, ORNL Waste Management will be required to take emergency action within the next 6 months to reduce the volume of the aqueous phase to a safe level within Tank WC-14. The liquid waste would be pumped into an interim storage facility.

\section{OUTSTANDING POLICY ISSUES}

There are no outstanding policy issues.

\section{ENFORCEMENT}

This time-critical removal at WAG 1 for Tank WC-14 is an action under the auspices of the FFA for ORR (DOE 1992). Enforcement options are included within this agreement of which DOE, EPA, and TDEC are parties.

\section{RECOMMENDATION}

This decision document represents the selected removal action for ORNL WAG 1, Tank WC-14 liquid removal on the DOE ORR in Oak Ridge, Tennessee. It is developed in accordance with CERCLA and is consistent with the NCP. This decision is based on the administrative record for the site. 


\section{REFERENCES}

DOE (U.S. Department of Energy). 1988. Order 5480.11, "Radiation Protection for Occupational Workers," December.

DOE. 1990. Order 5400.5, "Radiation Protection of the Public and the Environment," February.

DOE. 1992, Federal Facility Agreement for the Oak Ridge Reservation, DOE/OR-1014, U.S. Department of Energy-Oak Ridge Reservation, Oak Ridge, Tennessee.

EPA (U. S. Environmental Protection Agency). 1990. Guidance on Remedial Actions for Superfund Sites with PCB Contamination, EPA/540/G-90/007, Office of Emergency and Remedial Response, Washington, D.C.

Johnston, J.D. 1994. Letter to W. Nelson Lingle, U.S. Department of Energy, Oak Ridge, TN

Lingle, W. N. 1994. Letter to C. Brown, U.S. Environmental Protection Agency,-Atlanta, Georgia and D. McCoy, Tennessee Department of Environment and Conservation, Oak Ridge, Tennessee.

Parrott, J.R., Jr.; Abraham, T.J., Jr.; Kent, T. J.; Taylor, P.A. 1991. Oak Ridge National Laboratory Liquid Waste Treatment Systems Waste Acceptance Criteria, WM-WMCO201, Martin Marietta Energy Systems,Inc. Oak Ridge, Tennessee 


\section{APPENDIX A}

\section{U.S. DEPARTMENT OF ENERGY AND U.S. ENVIRONMENTAL PROTECTION AGENCY LETTERS}




\title{
Department of Energy
}

\author{
Oak Ridge Operations \\ P.O. Box 2001 \\ Oak Ridge, Tennessee 37831-8541
}

January 28,1994

Mr. Craig Brown

U.S. Environmental Protection Agency

Region IV

345 Courtland Street, N. E.

Atlanta, Georgia 30365

Mr. Doug McCoy, FFA Project Manager

DOE Oversight Division

Tennessee Department of Environment

and Conservation

761 Emory Valley Road

Oak Ridge, Tennessee 37830-7072

Gent Temen:

\section{FEDERAL FACILITY AGREEMENT - TANK WC-14 - POLYCHLORINATED BIPHENYLS}

Tank WC-14 is a stainless steel, below-grade 1,000 gallon tank installed as part of the liquid low-level waste (LLLW) system at Oak Ridge National Laboratory (ORNL) in 1951. The enclosed figure presents a schematic of the liquid waste system at ORNL. Tank WC-14, which was removed from active service in January 1992, contains residual waste from past operations and occasionally receives non-programmatic inflows. It is classified as a Category $D$ (inactive) tank in the Federal Facility Agreement (FFA). The contents of this tank consist of both liquid and sludge phases. The liquid phase was sampled in November 1992, and analytical results showed the liquid phase contained approximately 278 parts per billion (ppb) polychlorinated biphenyls (PCBs). The sludge phase of Tank WC-14 was sampled in March and August 1993, and analytical results showed that the concentration of PCBs in the sludge ranged from 105 to 241 parts per million (ppm). Physical characteristics of the sludge were described as "a sticky consistency mixed with a small amount of $0 i 1 "$. The sludge contains significant quantities of gamma-emitting radionuclides (e.g., cobalt and europium) and alpha-emitting transuranics (e.g. plutonium and americium) which generate significant penetrating radiation and inhalation hazards respectively. The quantity of sludge is approximately 50 gallons and principally resulted from advanced reactor fuel extraction experiments conducted during the 1950s, 1960s, and 1970s. No research involved PCB usage, and the presence of PCBs in the tank was unexpected. Tank $W C-14$ was constructed to receive radioactive 1 iquid wastes, and was never intended to receive waste containing PCBS. A review of facility operations in the area of Tank WC-14 does not indicate any recent use of PCBs or a known pathway for entry of PCBs into the tank. Administrative controls to prevent discharge of PCBs or other non-desirable materials into the liquid waste systems were implemented prior to May 4, 1987, resulting from the assurance of the Toxic Substances Control Act [TSCA] PCB Spill Cleanup Policy). 
Mr. Craig Brown

Mr. Doug McCoy

In order to maintain full statutory and regulatory compliance with the TSCA, we are requesting the Environmental Protection Agency (EPA) concurrence on the following items:

1. An exemption is requested from the antidilution provision of the PCB regulations for the aqueous phase of Tank WC-14 to allow discharge to the LLLW system. This documents that EPA recognizes as an exemption to the antidilution provision that all prior and subsequent liquid discharges from the LLLW system would not be classified as TSCA PCB waste.

Solidified waste forms resulting from the 1 iquid waste system would not be subject to TSCA PCB storage and disposal requirements.

2. Acceptance of this letter as written notification that a "historical spill" of PCBs in concentration greater than $50 \mathrm{ppm}$ has been discovered in sludges in Tank WC-14 of the LLLW system at ORNL.

3. The "spill" of PCBs into Tank WC-14 as an "exceptional spill situation that requires less stringent cleanup or different approach to cleanup because of factors associated with the particular spill". [See 40 CFR $761.120(a)(4)(1992)$.$] The PCB Spill Cleanup Policy provides EPA with the$ flexibility to allow alternative decontamination measures based upon site-specific considerations. Site-specific criteria for cleaning up the spill from Tank WC-14 should be employed since. the waste generated from the LLLW System is highly radioactive and must be managed in accordance with regulatory requirements for the storage, treatment, and disposal of radioactive waste. The hazards associated with radionuclides preclude application of standard PCB cleanup measures.

4. Since remediation of the $L L L W$ system is provided for in the FFA between EPA, Tennessee Department of Environment and Conservation, and the Department of Energy, the residual sludge and Tank WC-14 can be remediated under the FFA through the Comprehensive Environmental Response Compensation, and Liability Act process.

We would appreciate your response to this request by February 18, 1994.

If you have any questions, please contact Cavanaugh Mims at (615) 576-9481 or Mac Roddye at (615) 576-1801.

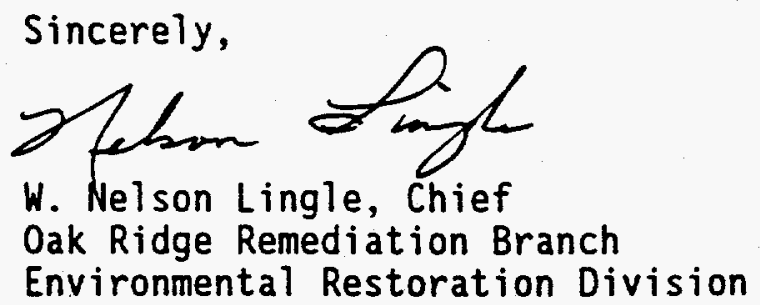

Enclosure

See ccs on page 3 
Mr. Craig Brown

Mr. Doug McCoy

cc w/enclosure:

C. Pi1j, EM-321, TREV II

R. Hultgren, ER-10, ORO

C. Mims, EW-911, ORO

M. Roddye, EW-922, ORO

J. Sweeney EW-911, ORO

P. Halsey, 1310-J, MS-7256

R. Mason, 3047, MS 6023

D. Turner, 3503, MS 6316 


\section{Schematic of the L.quid Waste System}

Melton Valley

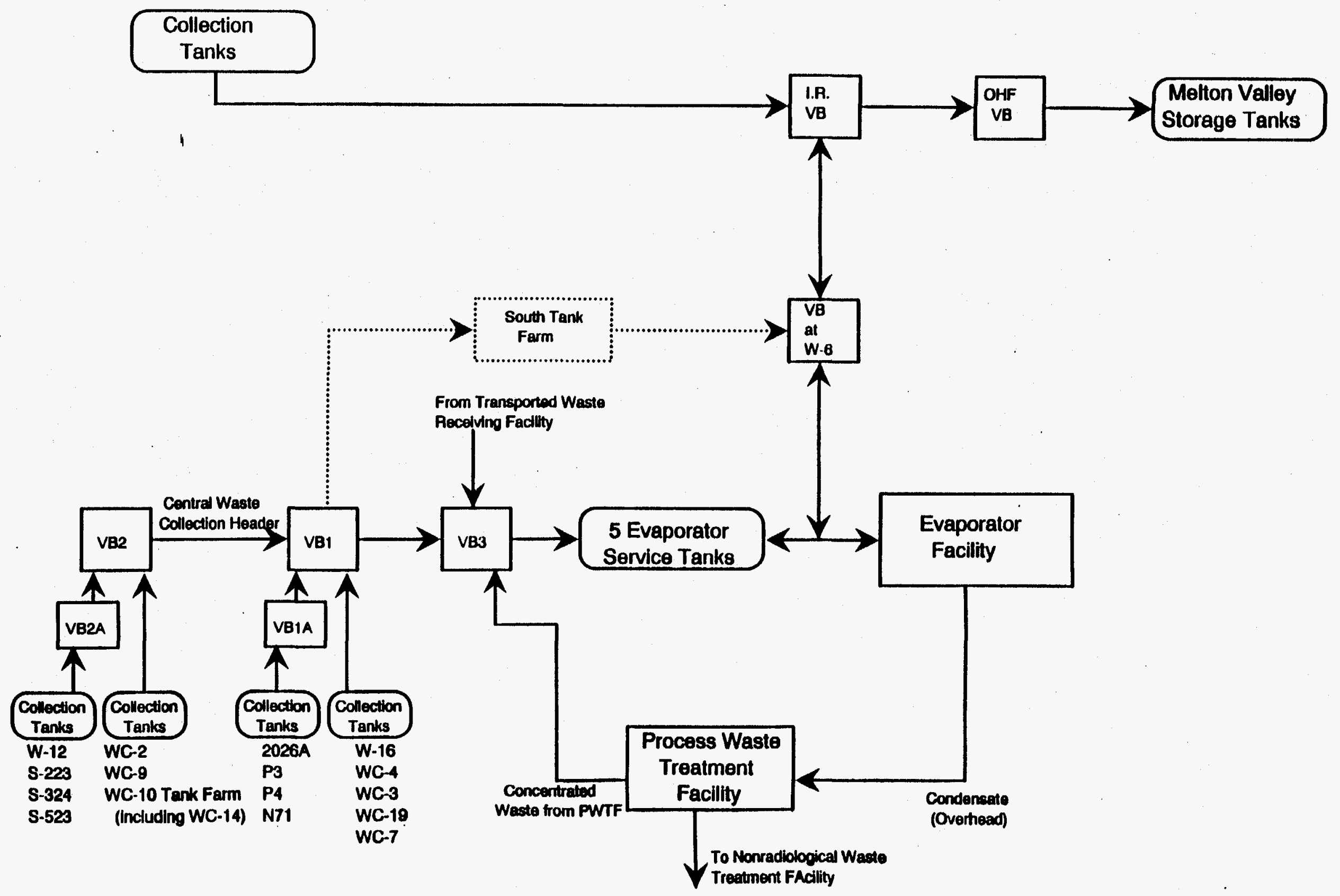




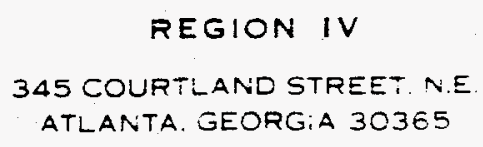

\section{N13 1,7 ISP}

4WD-FFB

W. Nelson Lingle

Environmental Restoration Division

U.S. Department of Energy

Oak Ridge Operations

P.O. BOX 2001

Oak Ridge, Tennessee 37831-8541

SUBJ: Tank WC-14 Polychlorinated Biphenyl (PCB) Contamination

Dear Mr. Lingle:

The Environmental Protection Agency (EPA) has reviewed the correspondence submitted by the Department of Energy (DOE) dated January 28, 1994, concerning tank WC-14 at the Oak Ridge National Laboratory (ORNL). As stated in DOE's correspondence, this tank contains approximately 50 gallons of sludge containing significant concentrations of gamma and alpha emitting radionuclides. This sludge also contains PCBs at concentrations between 105 to 241 parts per million (ppm). The tank contains several hundred gallons of radioactive liquid low level waste (ILLW) that has PCB levels of approximately 278 parts per billion (ppb). DOE has stated in project manager meetings for the ORNL that PCBs have not been detected in any portion of the LLLW system with the exception of tank WC-14. Based upon the information provided by DOE, it appears that WC-14 was contaminated by a historical release of approximately 0.3 pounds of PCBs.

The active and inactive portions of the LILW system at ORNL consists of approximately 100 waste tanks and 36,000 feet of piping. This system has been used to handle radioactive wastes at ORNL since plant construction in the 1940's. The majority of this system is either physically inaccessible or inaccessible due to elevated area radiation levels.

Prior to detecting the PCBs in WC-14, DOE discharged the aqueous phase contents of WC-14 to the LLLW system on several occasions. The discharged waste was concentrated at the waste evaporator and is being stored in the Melton Valley Storage Tanks (MVSTs). The MVSTs consist of eight (8) 50,000 gallon tanks used for the storage of concentrated LILW. These tanks contain a mixture of wastes, including transuranic radioactive waste, and are serving as an interim storage facility until the waste can be processed and sent for final disposal at an approved waste repository. 
DOE has recognized that there is a national need for engineered repositories to safely store transuranic radioactive wastes such as the waste in the MVSTs. Repositories such as the waste Isolation Pilot Plant are intended to safely receive and store this type of waste from the DOE complex to minimize the potential hazards to humans and the environment. DOE anticipates that the waste Isolation Pilot Plant will serve as the final repository for the wastes in the MVSTs. The Waste Isolation Pilot Plant is intended for long-term storage of transuranic wastes and provides for waste containing other contaminants as well.

Pursuant to Section 120 of the Comprehensive Environmental Response, Compensation, and Liability ACt (CERCLA), the Tennessee Department of Environment and Conservation (TDEC), DOE, and EPA entered into a Federal Facility Agreement (FFA) that became effective on January 1, 1992. LLLW tank systems are currently covered under the provisions of the FFA.

The LILW system consists of active and inactive components. Active portions of the LLLW system must either be doubly contained or undergo periodic structural integrity assessments including leak tests. Active singly contained portions of the LLIW system are scheduled for upgrading or replacement. For tank systems which are removed from service, DOE is required to remediate the tank system, including the tank contents, the tank and related piping and appurtenances, and any surrounding releases or contamination. Remediation activities conducted pursuant to the FFA are to be done in accordance with the requirements of the National Contingency Plan (NCP) of CERCLA and all applicable or relevant and appropriate requirements (ARARs) such as the Toxic Substances Control Act (TSCA).

Tank WC-14 is a tank that has been removed from service, but still receives occasional input of potentially radioactively contaminated water from non-programmatic sources. These sources are the result of unvalved gravity drain lines and other feed lines from current and historic plant operations that have discharged into the LILW system. Some of these non-programmatic sources are not identified in available design drawings. DOE is currently attempting to identify and isolate such sources of input into WC-14 and other inactive tanks. This has not yet been accomplished for WC-14.

Historic plant operations and occasional non-programmatic inflows have resulted in the build-up of sludge in WC-14 and are the source of the current liquid contents. The source of PCBs into this tank and the date of introduction are unknown. However, DOE believes that the PCBs were introduced prior to implementing administrative controls to prevent the discharge of PCBs into the LLLW system in 1987. 
In DOE's correspondence, DOE requested EPA's concurrence on several items regarding the handling of this $\mathrm{PCB}$ release and its impact on the LWLW system. EPA's response is as follows. DOE will address remediation of all releases from the LIIW system and remediation of all tank systems removed from service in

accordance with the terms of the FFA. Waste contained within the active portions of the LILW system which DOE operates in accordance with its own authorities must be sent to permitted waste handling/disposal facilities and meet all applicable waste acceptance criteria for that facility. PCB handling and disposal requirements for the LLLW system will be addressed as part of the overall remediation of the HILW system as implemented through the FFA. Therefore, CERCLA response actions for the IILW system and its releases will address TSCA requirements as an ARAR. The contents of the active IILW system which have been comingled with discharges from Tank WC-14 must be sent to a facility permitted to accept waste with the contaminants and concentrations of the ILLW system waste being transferred for disposal. EPA bases these decisions on the following considerations.

- The 0.3 pounds of PCBs represent a negligible portion of the human health and environmental risk posed by the approximately 400,000 gallons of LLLW.

- The LLLW tank systems, including all releases, are covered under the provisions of the Oak Ridge Reservation FFA. The CERCLA remedy selection process will address the environmental and human health risks associated with the PCBs, radioactive waste, and other hazardous substances in the LLLW system.

- The contents of the active LLLW system operated by DOE must be sent to permitted facilities for disposal. Disposal of the waste in a protective manner will be regulated through the receiving facility's waste handling and disposal permit and application of waste acceptance criteria.

- Based upon information provided by DOE, treatment of the approximately $0: 3$ pounds of PCBs released into Tank WC-14 and the LILW system would be difficult, costly, generate an additional mixed radioactive waste/PCB wastestream, and result in elevated personnel exposures to radiation.

EPA is currently negotiating a Federal Facility Compliance Agreement (FFCA) with the Oak Ridge Reservation to address all PCB issues at the Reservation. The FFCA will include a section addressing the ORNL LLLW system and it will defer remediation of the LLLW system to the FFA already in place. The solidified LLLW blocks generated from MVST supernatant may be disposed in a 
facility permitted to receive wastes of the contaminants and concentrations present in the blocks. However, any future discharges or discovery of additional PCB contamination within the LLLW system may result in strict application of the TSCA requirements and/or renegotiation of the FFCA.

Questions or comments regarding this matter should be addressed to Mr. Edward M. Carreras, Remedial Project Manager at (404) 347-3016.

Sincerely,

Grivanen in

Jon D. Johnston, Chief

Federal Facilities Branch

waste Management Division

cc: Denisse Davilla, EPA

Jon Richards, EPA

Doug MCCOY, TDEC

John Sweeney, DOE-ORO

Mac Roddye, DOE-ORO

Pat Halsey, MMES 